\title{
Diversity of Ornamental Fishes in Lower Manair Dam at Karimnagar Dt. Andhra Pradesh.
}

\author{
K. Rama Rao \\ Department of Zoology Govt. Degree College Jammikunta, Karimnagar, Dt. Andhra Pradesh, India
}

\begin{abstract}
The freshwater ornamental fishes in the Lower Manair Dam were studied from August-2012 toJuly2013. Samples were collected every week with help of local fishermen by using fishing nets and bamboo traps. In one year study period, 53 species of ornamental fishes were recorded in Lower Manair Dam. The recorded fishes belong to 8 orders, out of these orders cypriniformes was dominant with 23 species contributes $43.40 \%$ in 2 families followed by Perciformes 11 species (20.76\%) 6 families, Siluriformes 9 species (16.98\%) in 5 families, Channiformes 4 species (7.85\%) in 1 family, Beloniformes 2 species (3.77\%) 2 families, Angulliformes 2 species (3.77\%) 1 family, Osteoglossiformes one species and Mogiliformes one species (1.87\%) in each family. Of these, 13 species were abundant, 13 species were common, 19 species were moderate and seven species were rare. Family cyprinidae was dominant with 10 genera and genus Puntius was dominant with 5 species followed by other species, IUCN (2013.2) and CAMP (1998) conservation status of each fish was listed. Key words: Ornamental fishes, Cypriniformes, IUCN, CAMP.
\end{abstract}

\section{Introduction}

Lower Manair Dam (LMD) is situated in Karimnagar District of Telangana region. This is a large new impoundment of Godavari basin with medium productive potential. The Lower Manair Dam is situated at Katiya Canal about $146.00 \mathrm{~km}$ to $234 \mathrm{kms}$ and Distributaries D 84 to D 94 and DBM 1 to DBM2. LMD water goes upto 2,62,326 acs, catchment area of river 6,475 sq.m. Reservoir full level is 280.416 mt. Full capacity of reservoir $0.68 \mathrm{TM}$ Cusmecs. Water spread area is $81.024 \mathrm{sq}$. kmt. LMD is used to provide employment to over 1000 fisher men every year. Fishing licence is issued to 311 fishermen during fishing season. Ornamental fishes usually mean attractive colourful fishes of various characteristics, which are kept as pets in confined space of an aquarium or a garden pool for fun and fancy. Ornamental fishes are usually kept in glass aquarium and hence popularly known as 'Aquarium Fishes'. These living jewels need not always have bright colours; as sometimes their peculiar characteristics such as body colour, morphology, mode of taking food etc. may also add to their attractiveness. About 600 ornamental fish species have been reported worldwide from various aquatic environments. Already 217 fish species belonging to 136 genera has been identified in North Eastern Region, of which about 150 species have been reported to be of ornamental value and in case of more than 50 species, overseas demand has been established. Keeping of aquarium has emerged as the second most popular hobby in recent years, next to photography. The ever-increasing demand for aquarium fishes gradually paved the avenue towards global trade of ornamental fishes. India's overall trade presently is over Rs. 150 million. Ornamental fish is one of the important items among the various types of commercially important fishes marketed nationally and internationally. Ornamental fishes are exported to 27 countries, which amounted to $2568 \mathrm{Mt}$ ( 0.86 per cent of the total marine export) in terms of quantity and US\$14 million ( 0.50 per cent of total marine export) in terms of value (MPEDA, 2007). Most of the aquatic weeds directly act as the perspective spawning ground for large growing reservoir fishes along with a large number of Ornamental fishes.

\section{Materials And Methods}

Ornamental fish samples were collected from different corners of LMD surrounding areas mainly fishermen, fish collectors, local fish markets, and fish sellers. Different types of nets (Drag nets, Push nets, Cast nets Stationary gill nets) and Bamboo baskets (Traps) were used for collection of fishes. The photographs of the collected fishes were taken at fresh condition immediately and preserve in $10 \%$ formalin without any postmortem stages and recorded vernacular name (Hamilton-Buchanan,F(1822), Mishrs, K.S, (1962), Munro, ISR (2000). Sample fishes were brought to the laboratory and fix in this solution in separate glass jars according to size. Smaller fishes were directly placed in the $10 \%$ formalin solution and larger fishes were given an incision on the abdomen and removed the gut content before they were preserved. The fishes collected and fixed were labelled giving serial numbers, date of collection, exact locality from where collected. Identification was done based on keys for fishes of the Indian subcontinent (Day.F (1958), Jairam, K.C,(1981)(1999), Talwar, PK and Jhingran,A. (1991) and classification was carried out on lines of Day.F(1889), (1958), Jairam, K.C(1961), Nelson (1976) Identification of the species was done mainly on the morphometric and meristematic characters. 


\section{Results}

The results of the present study revealed that the occurrence of fifty three ornamental fish species belong to eight orders, 19 families and 34 genera. List of ornamental fish including their order, family, species, common name and vernacular name were recorded in the present investigation was given in Table 1 . The listed species are Labeo ariza, Labio bata, Labio calbasu, Labio fimbriatus, Cirrhnus reba, Cyprinus carpio, Garra gotyla gotyla, Osteobrama cotio cotio, Puntius chola, Puntius ticto, Puntius sarana sarana, Puntius sarana, Puntius sophore, Rasbora daniconius, Rasbora elanga, Salmostoma phulo, Salmostoma bacaila, Amblypharyngodon microlepis, Amblypharyngodon mola, Danio devario, Lepidocephalicthys berdmorei, Lepidocephalicthys guntea, Schistura cirica, Mystus bleeker, Mystus cavasius, Mystus tengra, Mystus vittatus, Ompok bimaculatus, Wallago attu, Clarias batrachus, Eutropneustes vacha, Heteropneustes fossilis, Anguilla bengalensis bengalensis, Anguilla bicolor bicolor, Notopterus notopterus, Xenentodon cancila, Hyporhampus gaimardi, Channa striatus, Channa panctatus, Channa marulius, Channa orienalis, Glosogobius giuris, Mastacembelus armatus, Mastacembelus pancalus, Trichogaster faciatus, Colisa lalio, Nandus nandus, Oreochromis mossambicus, Etroplus suratensis, Etroplus maculatus, Chanda nama, Ambassis ranga, Rhinomugil corsula.

The number and percentage composition of families, genera and species under different orders are shown in Table 2 and Fig 2,3,4. Order cypriniformes was dominant with 23 species contributing $43.40 \%$ of the total species followed by Perciformes with 11 (20.76\%), Siluriformes 09 (16.98\%), Channiformes 04 (7.55\%), Anguilliformes and Beloiniformes each 02 (3.77\%), Osteoglossiformes and Mogiliformes each 01 (1.87\%). Recorded families out of 19, Perciformes contributed 06 (31.58\%) families followed by Siluriformes 05 (26.32\%), Cypiniformies and Beloiniformes each with 02 (10.53\%), Anguilliformes, Osteoglossiformes, Channiformes and Mogiliformes each with 01 (5.26\%). Recorded genera's out of 34 species, Cypiniformies contributed $13(38.24 \%)$ species followed by Perciformes 09 (26.42\%), Siluriformes 06 (17.65\%), Beloiniformes with 02 (5.88\%), Anguilliformes, Osteoglossiformes, Channiformes and Mogiliformes each with 01 (2.94\%). Out of 34 genera genus Puntius was dominant with 5 species followed by Labeo, Channa and Mystus with each 4 species, Rasbora, Salmostoma, Amblypharyngodon, Anguilla, Mastacembelu and Etroplus each with 2 species, Cirrhinus, Cyprinus, Garra, Osteobrama, Danio, Lepidocephalichthys, Schistura, Acanthocobitis, Ompok, Wallago, Clarias, Eutropiichthys, Heteropneustes, Notopterus, Xenentodon, Hyporhampus, Glossogobius, Trichogaster, Colisa, Nandus, Oreochromis, Chanda, Ambassis, Rhinomugil with each one species shown in Table: 3.

The number and percent composition of genera and species under various families are presented in Table: 4. Fig. 1. The generic composition of fishes belonging to different families shows that ten genera under family Cyprinidae contributes to $30.30 \%$, five genera each under Cobitodae, Siluridae, Anabantidae, Cichlidae and Ambassidae contributes to $6.06 \%$ and thirteen genera each under Bagridae, Clariidae, Schilbeidae, Heteropneustidae, Anguillidae, Notopteridae, belonidae, Exocoetidae, Channidae, Gobiidae, Mastacembelidae, Nandidae and Mugilidae contributes to $3.03 \%$. The species composition of fishes belonging to different families have revealed that twenty species are belonging to family Cyprinidae that made up to $37.74 \%$, four species are belonging to the family Bagridae and Channidae each contributes to $7.55 \%$, three species of families Cobitidae and Cichlidae contributes to $5.66 \%$, two species to each families Siluridae, Anguillidae, Mastacembalidae, Anabantidae and Ambassidae contribue $3.77 \%$ and one species of each families Clariidae, schilbeidae, Heteropneustidae, Notopteridae, Exocoetidae, Gobiidae, Nandidae and Ambassidae contributing $1.87 \%$ each of the total fish species. Table: 3 .

Conservation status of the ornamental fishes from Lower Manair Dam is presented in Table 1, and percentage occurrence of fish under IUCN (2013.2) and CAMP conservation status is given Table. 5 and Fig. 5 , 6. The status of fishes of India in Conservation Assessment and Management Programme (1998) were categorized into 10 different groups of fish viz., Extinct (EX), Extinct in the wild (EW), Critically Endangered (CE), Endangered (EN), Vulnerable (VU), Lower risk near threatened (LRnt), Lower risk least concern (LRlc), Lower risk conservation dependent (LRcd), Data deficient (DD) and Not evaluated (NE). In this present study 53 ornamental fishes are reported, out of these $1.92 \%$ species are endangered, $1.92 \%$ species are vulnerable, $5.77 \%$ species are near threatened, $84.62 \%$ lower risk, $1.92 \%$ data deficient, $3.85 \%$ not evaluated as per IUCN (2003.2). Where as $5.76 \%$ species are endangered, $19.23 \%$ species are vulnerable, $32.69 \%$ species are lower risk and near threatened, $1.92 \%$ lower risk and least concern, $1.92 \%$ data deficient and $38.46 \%$ not evaluated according to CAMP (1998), shown in Table 5.

\section{Discussion}

The present study in Lower Manair Dam revealed that the occurrence of fifty three ornamental fish species belongs to 8 orders, 19 families and 34 genera, out of the total fishes order cypriniformes was dominant with 22 species of the total fish species followed by Perciformes, Siluriformes, Channiformes, Anguilliformes, Beloiniformes, Osteoglossiformes and Mogiliformes. Recorded families out of 19, Perciformes contributed 06, 
families followed by Siluriformes 05, Cypiniformies and Beloiniformes each with 02, Anguilliformes, Osteoglossiformes, Channiformes and Mogiliformes each with 01. Garg et al., (2007) have studied that the fisheries of Ramsagar reservoir, Data recorded 42 fish species belonging to 28 genera, 15 families and 8 orders. Order cypriniformes with 21 species showed maximum species diversity while the minimum fish species diversity was shown by order Beloniformes and Synbranchiformes with only one species. North-Eastern States are endowed with vast aquatic resources with great diversity of ornamental fishes; the ornamental fishes are diversified over 37 families, 114 genera and 10 orders. Out of the total 274 fish species reported from this region, around 250 species (91 per cent) possess ornamental value. The major species having a large number of ornamental fishes belong to the Order Cypriniformes, followed by Siluriformes and Perciformes reported by Subhasis Mandal et al (2007). M. Tirupathaiah et al (2013) has reported that a total of 44 species of fishes belonging to 8 orders such as Cypriniformes (18 species) Siluriformes (11species), Perciformes (6 species), Channiformes (4 species) Beloniformes(2 species), Angulliformes (one species) Osteoglossiformes (one species) and Mogiliformes(one species). Of these, 24 species of fish are least concerned, 8 are data deficient (DD), 10 are not evaluate (NE), 1 species of fish is vulnerable and 1 species of fish is near threatened. Chakravartty,P et al., (2012)conducted a Survey on the Fish Diversity with Special Reference to the Classified Ornamental Fishes and their Prospects in the Kalpa Beel of Barpeta District. Chakravartty, et al., ( 2013) reported to a survey on the fish diversity in Nalbari district of Assam with special reference to the classified ornamental fishes. Among the wild catch fishes exported from the country, West Bengal and the North-Eastern states are the major contributor by (Mahapatra et al., (2006). In the field of ichthyology valuable contribution were made by Jaiswal, D. P. \& Ahirrao, K. D. (2012), Pramod Kumar et al (2011), Chatoan Tesia \& Sabitry Bordoloi (2012), Das, M. K. \& Sabitry, B. (2012), and Ichthyofaunal diversity of the Rangavali Dam, Navapur, and Shershah Suri Pond, Sasaram, Bihar. Anish Dua \& Chander Parkash (2009), Chandra Sekhara Rao et al (2013), observed that the distribution and abundance of fish populations and investigation of aquaculture dynamics at a Ramsar site and ornamental Fish Diversity of Lake Kolleru with a socio-economic assessment. Ghosh et al (2003).The largest wholesale ornamental fish market of eastern India. K.L. Tekriwal and A.A. Rao.(1998), studied on ornamental aquarium fish of India. Hamilton- Buchanan, F. (1822), Sarwade, J. P. \& Khillare, Y. K. (2010), Devi K. R and Indra T.J. (2012), Barman R.P., (1993), observed and reported a native freshwater fishes in different parts of India. Babu Rao (1997) has reported the fish fauna in Himayatsagar Lake in Hyderabad 32 fish species belonging to six orders with 11 families.

\section{Conclusions}

A number of ornamental fish species are available in Lower Manair Dam at early monsoon period and winter season. Puntius, Mystus, Amblypherangodon species are more dominant in all seasons. Macrognathgus and Channa species are second dominant in the LMD ornamental fishery. Presently, the freshwater ornamental fish diversity at Lower Manair Dam to restrict and checking the entry of exotic species coupled with more awareness on the indigenous species would go a long way in preserving rich Dam fish diversity. This sector is more vibrant and remunerative.

\section{Acknowledgements}

The author would like to thank University Grant Commission for rendering financial assistance and Commissioner Collegiate Education Andhra Pradesh, Govt. Degree College, Jammikunta, for providing necessary facilities.

\section{References}

[1] Anish Dua \& Chander Parkash (2009). Distribution and abundance of fish populations in Harike wetland-A Ramsar site in India. J. Environ. Biol., 30(2): $247-251$.

[2] Babu Rao M. (1997). Studies on the ecology and fish fauna of an oligotrophic lake Hamayatsagar Hydrabad (A.P.), Rec. Adv.In freshwater Biology, II (8), 123-138

[3] Barman R.P., (1993) Pisces: Freshwater Fishes, In: State fauna series 5, Fauna of Andhra Pradesh, Part-1, ZSI 89-334.

[4] CAMP (1998). Conservation and Management Plan for Freshwater Fishes of India". Organized by Zoo Outreach Organisation, NBFGR, Lucknow.

[5] Chakravartty, Pranjal, Sharma Subrata: 2013. A survey on the fish diversity in Nalbari district of Assam with special reference to the classified ornamental fishes. Online ISSN : 2231-5780. Volume : 3, Issue : 1First page : (170) Last page : (185)

[6] Chakravartty,P., Chakravartty, M. \& Sharma, S. (2012). A Survey on the Fish Diversity with Special Reference to the Classified Ornamental Fishes and their Prospects in the Kalpa Beel of Barpeta District. The Science Probe, 1.1(2): 12-21.

[7] Chatoan Tesia \& Sabitry Bordoloi (2012). Ichthyofaunal Diversity of Charju River, Tirap District, Arunachal Pradesh, India. Asian J. Exp. Bio. Sci., 3(1): $82-86$.

[8] Das, M. K. \& Sabitry, B. (2012). Ichthyofaunal Resources of Inland water Bodies of the River Island Majuli, Assam, India. Asian J. Exp. Bio. Sci., 3(1): $51-58$.

[9] Day, F. (1958). The fishes of India, being a natural history of the fishes known to inhabit the seas and freshwater of India, Burma and Ceylon, text and atlas, London, William Dawson and Sons Ltd., pp. 195-198.

[10] Day, F. (1889). The fauna of British India including Ceylon and Burma. Fishes. 1: 548: 2: 509. The London, Taylor and Francis. 
[11] Devi K. R and Indra T.J. (2012)Check list of the native freshwater fishes of India, Zoological Survey of India, http://zsi.gov.in/check_list.html

[12] R.K. Garg, R.J. Rao, D.N. Saksena, (2007 . Check list of fishes of Ramsagar reservoir Datia Distrect, Madya Predesh, India. Zoos’ Print Journal, 22(8), 2801-2803.

[13] Ghosh, A., B. K. Mahapatra and N. C. Datta (2003) Hatibagan Haat, Kolkata - The largest wholesale ornamental fish market of eastern India, Fishing Chimes, Vol.23(1):166-168.

[14] Hamilton- Buchanan, F. (1822). An account of the fishes of river Ganges and its branches. Edinburgh and London, vii + 450p.

[15] Indian Ornamental Fish- Wide verities and unique features. http://www.mpeda.com/aquarium/htmlorna/ornamentalfishfeedback1.htm

[16] IUCN Red List of threatened species, version 2013.2 www.iucnredlist.org down loaded on December 2013.

[17] J. Chandra Sekhara Rao, G. Simhachalam and Ch. Sebastian Raju 2013. Ornamental Fish Diversity of Lake Kolleru, the only Ramsar site in Andhra Pradeh, India. Bull. Env. Phrm. Life Sci. Vol 2(7): 48-55.

[18] Jairam, K. C. (1961). The proper generic names for some common Indian fishes of commercial importance. J. Zoo. Soc. India, 12(2): $239-242$.

[19] Jairam, K. C. (1981). The freshwater fishes of India, Pakistan, Bangladesh, Burma and Sri Lanka- A Handbook. Zoological Survey of India, Culcutta, $475 \mathrm{pp}$.

[20] Jairam, K. C. (1999). The freshwater fishes of the Indian region. Narendra Publicatin New Delhi, India, 551.

[21] Jaiswal, D. P. \& Ahirrao, K. D. (2012). Ichthyodiversity of the Rangavali Dam, Navapur, District Nandurbar, Maharashtra State. J. Res. Biol., 3: $241-245$.

[22] K.L. Tekriwal and A.A. Rao.1998, Ornamental aquarium fish of India. By Aquarium sciences and conservation Volume 2, Issue 4, p 256.

[23] M. Tirupathaiah, Ch. Samatha and Ch. Sammaiah 2013. Diversity of fish fauna in Lower Manair Reservoir of Karimnagar district (A.P.), India. Adv. In App. Sci. Res. 4(2):203-211.

[24] Mahapatra, B. .K., K. Vinod and B. K. Mandal (2005) Export potentiality of native ornamental fish from North-Eastern hill states of India with a note for development of such fisheries, Environment and Ecology, 23(4):780-786.

[25] Mahapatra, B. .K., K. Vinod and B. K. Mandal and K.M. Bujarbaruah (2006) Ornamental Fisheries in North Eastern India, Research Bulletin No. 49, ICAR Research Complex for NEH Region, Umroi Road, Umiam, Meghalaya.

[26] Mishra, S. (1962). An aid to the identification of the common commercial fishes of India and Pakistan. Rec. Ind. 1. Mus., 57: 1 320.

[27] Molur, S. \& Walker, S. (1998). Report of the Workshop "Conservation and Management Plan for Freshwater Fishes of India". Zoo Outreach Organisation, Conservation Specialist Group of India, Coimbatore, India.

[28] MPEDA (2007). Export Performance of Marine Products during 2005-06, http://www.mpeda.com.

[29] Munro, I. S. R. (2000). The Marine and Freshwater Fishes of Ceylon. Biotech Books, Delhi.

[30] Nelson (1976). Fishes of the World. 3rd Edn. John Wiley and Sons, New York, p. 416.

[31] Pramod Kumar, Rajni, W., Ashwani, W. \& Fozia, S. (2011). Preliminary Study on Icthyofaunal diversity of Shershah Suri Pond, Sasaram, Bihar. Int. J. Eng. Sci. Tech., 3(2): 1582-1588.

[32] Sarwade, J. P. \& Khillare, Y. K. (2010). Fish diversity of Ujani wetland, Maharashtra, India. The Bioscan, 1: $173-179$.

[33] Subhasis Manda11, B. K. Mahapatra2, A. K. Tripathi1.2007: Agribusiness Opportunities of Ornamental Fisheries in North-Eastern Region of India. Agr. Eco. Res. Rev. Vol. 20 (Conference Issue) 2007 pp 471-488.

[34] Talwar, P. K. and Jhingran, A. (1991). Inland fishes of India and Adjacent Countries. Oxford and IBH Publishing Co. Pvt. Ltd. New Delhi, Vol 1 \& II, 1158pp.

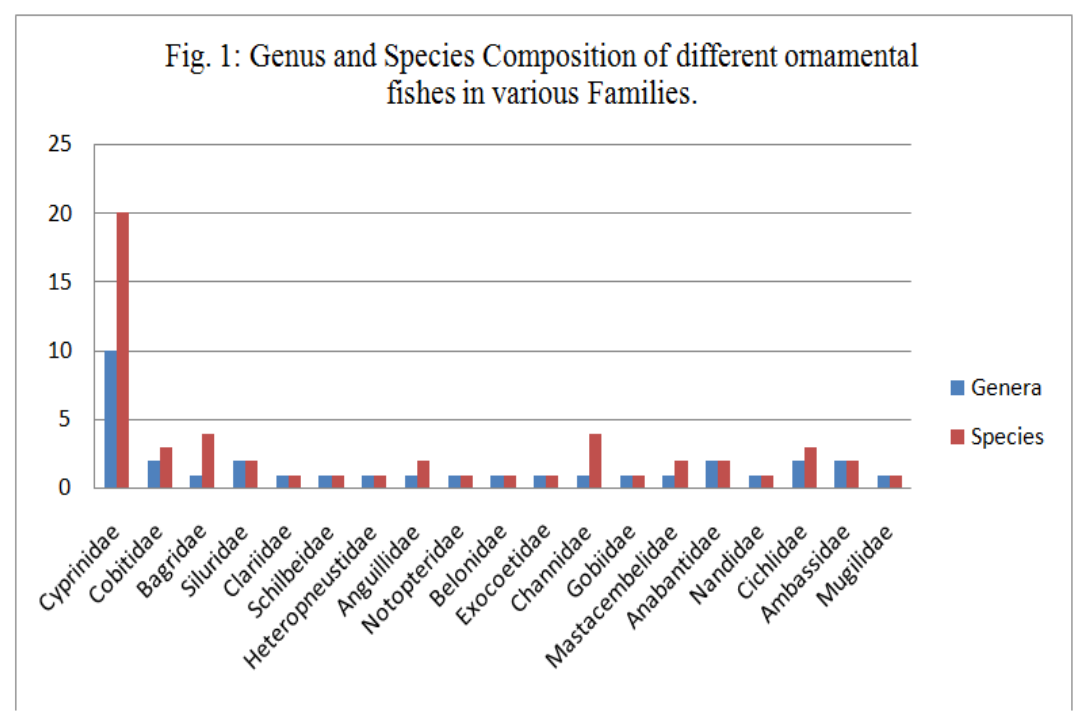



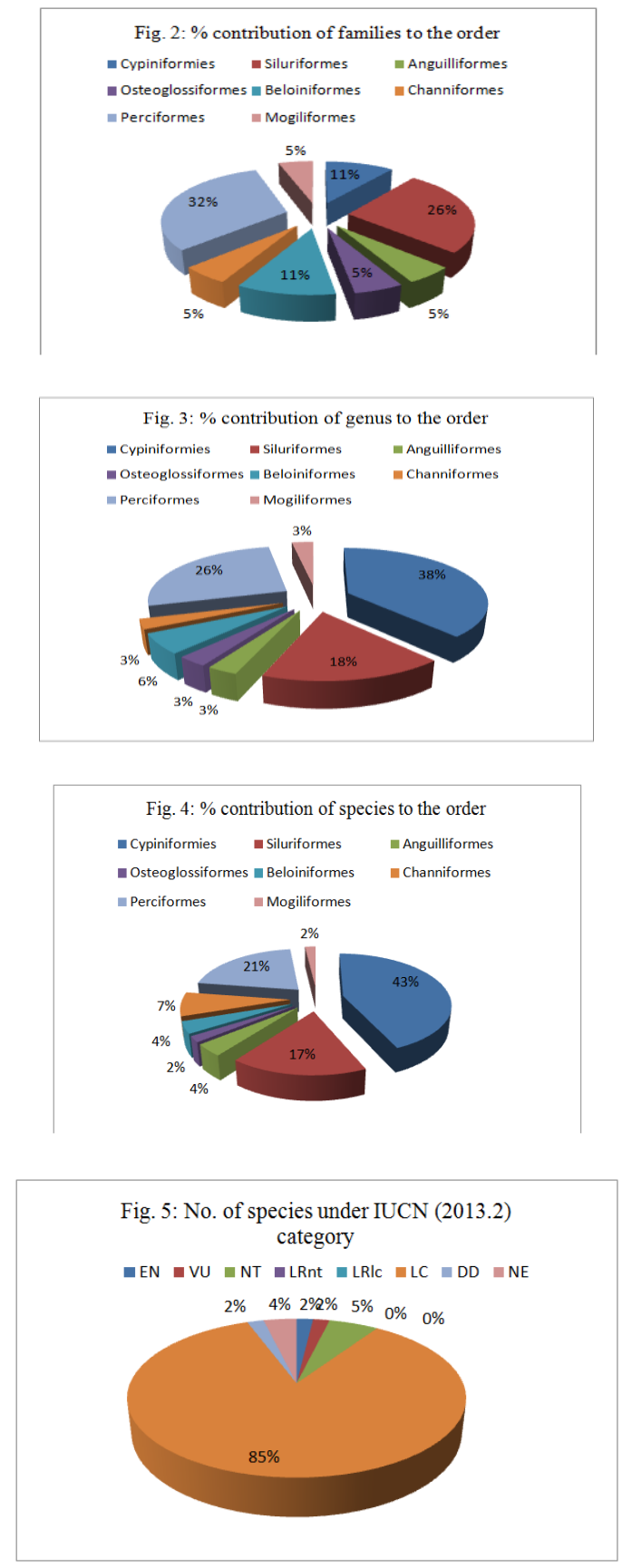

Fig. 6: No. of species under CAMP (1998) category

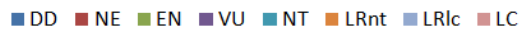
$2 \% 0 \% 2 \%$

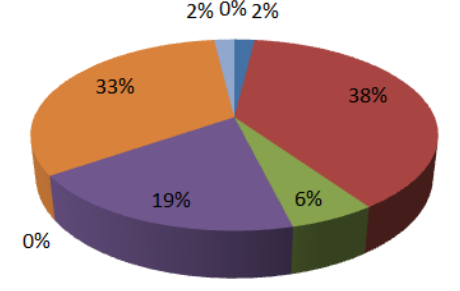

